$12-2004$

\title{
Earthquake Triggering at Alaskan Volcanoes Following the 3 November 2002 Denali Fault Earthquake
}

Seth C. Moran

John A. Power

Scott D. Stihler

John J. Sa 'nchez

Jacqueline Caplan-Auerbach

Western Washington University, jackie.caplan-auerbach@wwu.edu

Follow this and additional works at: https://cedar.wwu.edu/geology_facpubs

Part of the Geology Commons, Geophysics and Seismology Commons, and the Volcanology Commons

\section{Recommended Citation}

Moran, Seth C.; Power, John A.; Stihler, Scott D.; Sa'nchez, John J.; and Caplan-Auerbach, Jacqueline, "Earthquake Triggering at Alaskan Volcanoes Following the 3 November 2002 Denali Fault Earthquake" (2004). Geology Faculty Publications. 46.

https://cedar.wwu.edu/geology_facpubs/46 


\section{Bulletin of the Seismological Society of America}

This copy is for distribution only by

the authors of the article and their institutions in accordance with the Open Access Policy of the Seismological Society of America.

For more information see the publications section of the SSA website at www.seismosoc.org

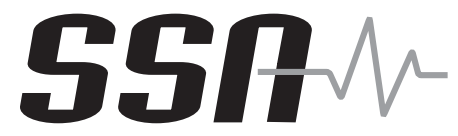

The Seismological Society of America 400 Evelyn Ave., Suite 201

Albany, CA 94706-1375

(510) 525-5474; FAX (510) 525-7204

www.seismosoc.org 


\title{
Earthquake Triggering at Alaskan Volcanoes Following the 3 November 2002 Denali Fault Earthquake
}

\author{
by Seth C. Moran, John A. Power, Scott D. Stihler, John J. Sánchez, and \\ Jacqueline Caplan-Auerbach
}

\begin{abstract}
The 3 November $2002 M_{\mathrm{W}} 7.9$ Denali fault earthquake provided an excellent opportunity to investigate triggered earthquakes at Alaskan volcanoes. The Alaska Volcano Observatory operates short-period seismic networks on 24 historically active volcanoes in Alaska, 247-2159 km distant from the mainshock epicenter. We searched for evidence of triggered seismicity by examining the unfiltered waveforms for all stations in each volcano network for $\sim 1 \mathrm{hr}$ after the $M_{\mathrm{W}} 7.9$ arrival time at each network and for significant increases in located earthquakes in the hours after the mainshock. We found compelling evidence for triggering only at the Katmai volcanic cluster (KVC, 720-755 km southwest of the epicenter), where small earthquakes with distinct $P$ and $S$ arrivals appeared within the mainshock coda at one station and a small increase in located earthquakes occurred for several hours after the mainshock. Peak dynamic stresses of $\sim 0.1 \mathrm{MPa}$ at Augustine Volcano $(560 \mathrm{~km}$ southwest of the epicenter) are significantly lower than those recorded in Yellowstone and Utah $(>3000 \mathrm{~km}$ southeast of the epicenter), suggesting that strong directivity effects were at least partly responsible for the lack of triggering at Alaskan volcanoes. We describe other incidents of earthquake-induced triggering in the $\mathrm{KVC}$, and outline a qualitative magnitude/distance-dependent triggering threshold. We argue that triggering results from the perturbation of magmatic-hydrothermal systems in the KVC and suggest that the comparative lack of triggering at other Alaskan volcanoes could be a result of differences in the nature of magmatic-hydrothermal systems.
\end{abstract}

\section{Introduction}

The fact that earthquakes can be triggered by remote large earthquakes was established after the 1992 Landers earthquake (Hill et al., 1993; Gomberg et al., 2001), with instantaneous increases in seismicity observed at distances of up to $1250 \mathrm{~km}$. Similar increases have since been observed after several large earthquakes, including the 1999 Hector Mine earthquake (e.g., Gomberg et al., 2001), at The Geysers after several large remote earthquakes (Stark and Davis, 1996; Gomberg and Davis, 1996), and at sites up to $3660 \mathrm{~km}$ distant from the 2002 Denali fault earthquake (e.g., Eberhart-Phillips et al., 2003). Remotely triggered seismicity often occurs in volcanically or geothermally active regions (e.g., Hill et al., 1993, 1995; Gomberg and Davis, 1996; Power et al., 2001; Hill et al., 2002; Husen et al., 2004; Prejean et al., 2004), although it has also been observed in nonvolcanic areas (e.g., Hill et al., 1993; Brodsky et al., 2000; Hough, 2001; Bodin et al., 2003; Pankow et al., 2004).

The 3 November $2002 M_{\mathrm{W}} 7.9$ Denali fault earthquake (DFE) was the first $M_{\mathrm{W}}>7.5$ event to occur in Alaska since modern seismic networks were established in the late 1990s by the Alaska Volcano Observatory (AVO) on many of the historically active volcanoes in Alaska. Previous investigators have found evidence of earthquake-volcano interactions at isolated volcanic centers in Alaska. These include a $M_{\mathrm{L}}$ 5.0 earthquake apparently induced by magma intrusion beneath Shishaldin volcano (Fig. 1) 1.5 months prior to its subPlinian eruption in 1999 (Moran et al., 2002), and triggered earthquakes beneath the Katmai volcanic cluster after the nearby $1999 M_{\mathrm{W}} 7.0$ Karluk Lake earthquake (Power et al., 2001). In this article we document the seismic response of volcanic areas in Alaska to the DFE, spanning a distance of 247 to $2159 \mathrm{~km}$ from the mainshock's epicenter (Fig. 1). We focus on the short-term (seconds to hours) response, because it is statistically easier to demonstrate a direct correlation between the triggering event and triggered seismicity. However, Sanchez and McNutt (2004) note that a possible longer-term quiescence may have occurred at Wrangell and Veniaminof volcanoes $(247 \mathrm{~km}$ southeast and $1050 \mathrm{~km}$ southwest of the mainshock, respectively) (see Fig. 1) in the intermediate-term (weeks to months) after the mainshock. We then describe the response of volcanoes within Katmai 


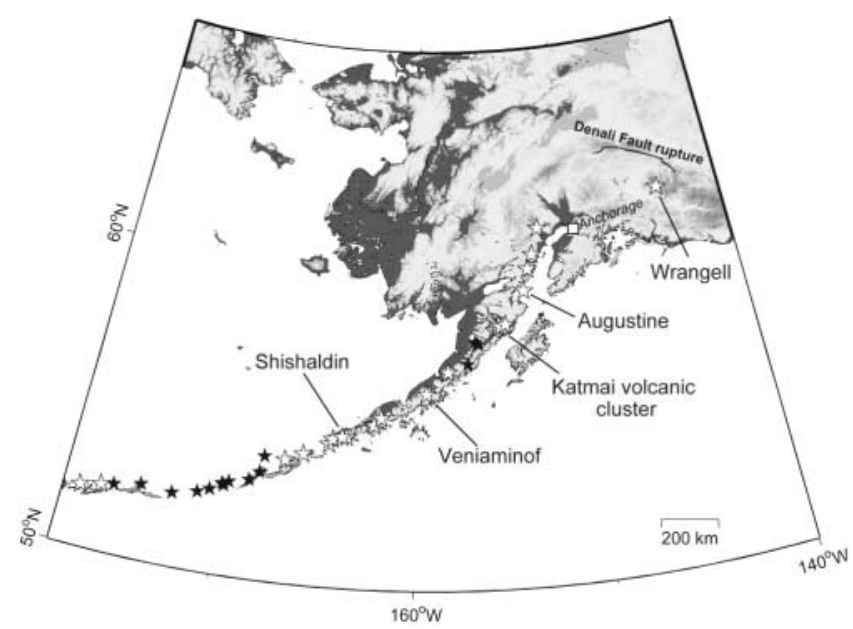

Figure 1. Map showing location of the Denali fault rupture relative to historically active volcanoes in Alaska (stars). White stars represent seismically monitored volcanoes; black stars represent unmonitored volcanoes.

National Park to four other large $\left(M_{\mathrm{W}} 6.8-7.0\right)$ earthquakes with hypocenters located $115-161 \mathrm{~km}$ from the volcanoes and explore the possible existence of a triggering threshold.

\section{Earthquake Triggering at Alaska Volcanoes}

\section{Background: Volcano Monitoring in Alaska}

AVO, a cooperative organization consisting of the U.S. Geological Survey, the University of Alaska at Fairbanks Geophysical Institute, and the Alaska Division of Geological and Geophysical Surveys, operated seismic networks on 24 of the $40+$ historically active volcanoes in Alaska at the time of the DFE (Dixon et al., 2003), spanning a distance of $\sim 2300 \mathrm{~km}$ along the Alaska/Aleutian volcanic arc (Fig. 1). AVO has been steadily increasing the number of seismically monitored volcanoes in Alaska since its inception in 1988, when it monitored only one volcano. At the time of the DFE, AVO recorded 178 channels of data from 140 stations (Dixon et al., 2003). Of these 140 stations, 123 have short-period vertical-component seismometers, 16 have short-period three-component seismometers, and one has a broadband sensor. A typical network on a single volcano consists of six short-period stations, with one three-component and five vertical-component seismometers. Seismic signals are placed on commercial phone circuits and sent to AVO operational centers in Fairbanks and Anchorage, where they are digitized at $100 \mathrm{samples} / \mathrm{sec}$, analyzed by automated and manual processes, and archived in both continuous and segmented formats (Dixon et al., 2003).

Response of Alaskan Volcanoes to the 2002 Denali Fault Earthquake

We used two criteria for determining whether triggered seismicity occurred at a given volcano: (1) the presence of local events (i.e., small $S$ - $P$ times, only recorded on local stations, etc.) in the coda of a large earthquake and (2) a significant short-term increase in the number of located local earthquakes. Immediately after the DFE we carefully looked at unfiltered and filtered waveforms for all stations in the AVO network for $1 \mathrm{hr}$ beyond the event onset. We found evidence for events in the coda only at several stations near a group of historically active volcanoes in Katmai National Park, referred to here as the Katmai volcanic cluster, or KVC. The earliest detected event appeared on station $\mathrm{ACH}, \sim 4$ min after the mainshock arrival (Table 1, Fig. 2). There was a small increase relative to background levels in located earthquakes in the KVC, with seven occurring during a 12hr period after the mainshock (Table 1). Four additional events were detected on $\mathrm{ACH}$ but were too small to be located.

We found no evidence of local events in the coda of the DFE at any other volcanoes. We also found no evidence of a short-term increase in the number of located earthquakes at any other volcano or in the AVO catalog as a whole. Because waveforms were clipped on all short-period stations for at least several minutes after the first arrivals, it is impossible to say definitively that no triggering occurred at other volcanoes besides the KVC. In particular, records from Wrangell, the volcano closest to the epicenter $(247 \mathrm{~km}$ southeast), were dominated by aftershocks for several days after the event, making assessment of short-term triggering particularly difficult. The one site that did stay on scale is the broadband station AUL on Augustine volcano (Fig. 1). AUL is located $2 \mathrm{~km}$ from the summit of Augustine and 560 $\mathrm{km}$ from the DFE epicenter; it has a Guralp CMG-40T sensor and DM24 digitizer. Figure 3 shows unfiltered and highpass-filtered 27-min-long records of the vertical component from AUL. The high-pass-filtered record shows no evidence of any local events, and none were found over later time intervals. Thus, at Augustine at least, we can definitively say that no triggering occurred in association with or after the passage of peak stress/strain transients.

Another form of evidence for negligible short-term effects at Alaskan volcanoes, other than those in the KVC, comes from the two volcanic systems that were seismically restless prior to the mainshock. There is good evidence that Veniaminof and Shishaldin volcanoes (Fig. 1) were not significantly perturbed in the short term by the mainshock. Figure 4 shows 24-hr helicorder plots, generated via the "Heli_ew" module of the EARTHWORM data-acquisition system (Bittenbinder et al., 1994), from before and after the mainshock at station VNSS on Veniaminof $(5.5 \mathrm{~km}$ northwest of the volcano and $\sim 1050 \mathrm{~km}$ southwest of the epicenter). Veniaminof had been exhibiting elevated seismicity in the form of low-frequency events $(1-2 \mathrm{~Hz})$ and tremor since 10 September 2002. Although an increase in wind noise makes the "after" 24 -hr helicorder plot difficult to read, it is still possible to see larger low-frequency events, and no obvious change in event rates or size is apparent. Figure 5a shows similar 24-hr plots from station SSLN on Shishaldin 
Table 1

Characteristics of Triggered Seismicity at Katmai

\begin{tabular}{cccccccc}
\hline $\begin{array}{c}\text { Event Date } \\
(\mathrm{mm} / \mathrm{dd} / \mathrm{yy})\end{array}$ & $M_{\mathrm{w}}{ }^{*}$ & $\begin{array}{c}\text { Depth } \\
(\mathrm{km})\end{array}$ & $\begin{array}{c}\text { Hypocentral } \\
\text { Distance to } \\
\text { Mageik }(\mathrm{km})\end{array}$ & $\begin{array}{c}\text { No. Located } \\
\text { Events within } \\
12 \mathrm{hr} .\end{array}$ & $\begin{array}{c}\text { Largest } \\
\text { Triggered } \\
\text { Event } \\
\left(M_{\mathrm{L}}\right)\end{array}$ & $\begin{array}{c}\text { Time from } \\
\text { Mainshock Arrivals } \\
\text { to First VT } \\
\text { in Coda }(\mathrm{sec})\end{array}$ & $\begin{array}{c}\text { Time from } \\
\text { Mainshock Arrivals } \\
\text { to First Located } \\
\text { Event }(\mathrm{sec})\end{array}$ \\
\hline $12 / 06 / 99$ & 7.0 & 60 & 115 & 17 & 2.3 & 171 & 605 \\
$07 / 11 / 00$ & 6.8 & 50 & 122 & 6 & 0.9 & - & 1133 \\
$01 / 10 / 01$ & 7.0 & 35 & 161 & 11 & 1.5 & 105 & 909 \\
$07 / 28 / 01$ & 6.8 & 128 & 161 & 0 & - & - & - \\
$11 / 03 / 02$ & 7.9 & 0 & 740 & 7 & 2.0 & 232 & 1135 \\
\hline
\end{tabular}

*Source parameters are from the National Earthquake Information Center.

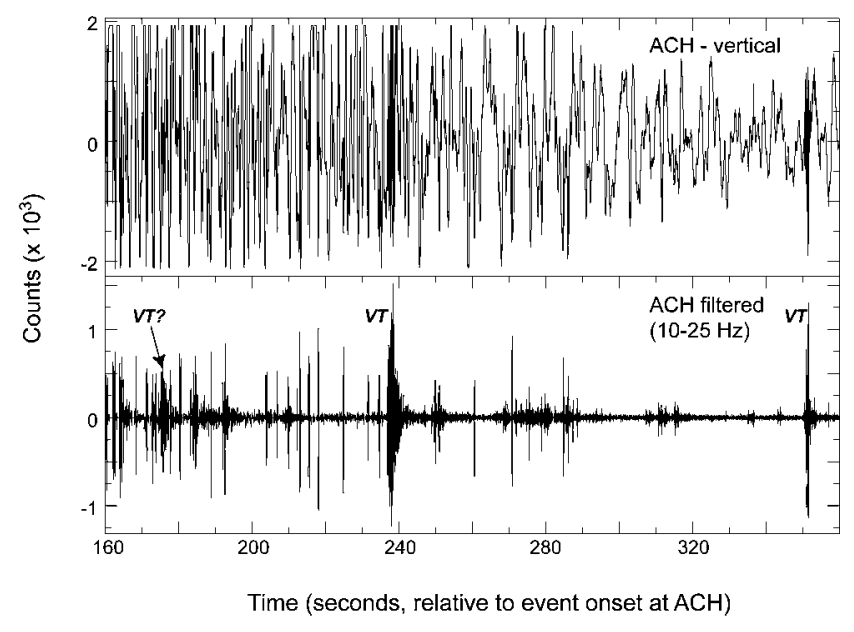

Figure 2. Unfiltered (top) and filtered (bottom) records from the vertical component of station $\mathrm{ACH}$, a short-period $(2-\mathrm{Hz})$ three-component station in Katmai National Park. Time is relative to the DFE $P$-wave arrival time at $\mathrm{ACH}$. The filtered record (high-pass filter with a $10-\mathrm{Hz}$ corner frequency) shows at least two, possibly three, local events (labeled "VT") occurring in the coda. Note that clipping occurs over much of the first $120 \mathrm{sec}$ in the unfiltered trace, resulting in noise spikes in the filtered trace.

(6.5 km north of the volcano and $\sim 1345 \mathrm{~km}$ southwest of the epicenter) before and after the mainshock. Both plots are dominated by small low-frequency events $(1-2 \mathrm{~Hz})$, which had been occurring relatively continuously at Shishaldin since late 1999 (Caplan-Auerbach et al., 2002). Visual comparisons show no obvious change in event rate or size during the $24 \mathrm{hr}$ after the DFE. A graph of hourly event counts made from each of these plots (Fig. 5b) further demonstrates no change in the seismicity rate after the mainshock.

The lack of evidence for seismicity changes at these two volcanoes was surprising. Because both were already seismically restless, presumably due to the presence of an active hydrothermal system fed by magma at relatively shallow depths, we hypothesized that pore pressures and volumetric and thermal stresses in the seismogenic region would be relatively high, thereby setting the stage for short-term seismicity increases. The absence of short-term changes is in

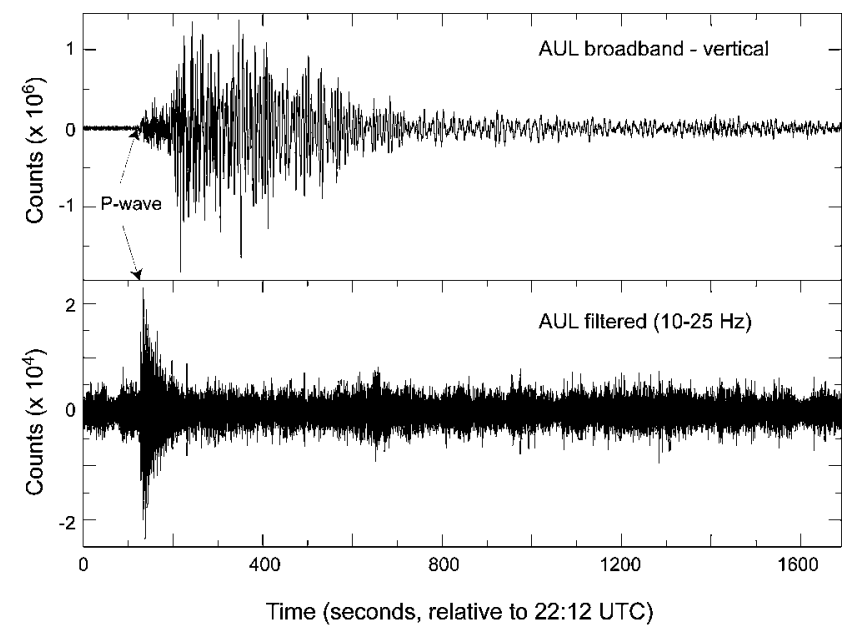

Figure 3. Unfiltered (top) and filtered (bottom) 27-min-long recording of the DFE at broadband station AUL, the only AVO station to stay on scale. The filtered record (high-pass filter with a $10-\mathrm{Hz}$ corner frequency) shows no evidence of local earthquakes in the coda.

contrast to fluctuations in tremor amplitudes observed at Shishaldin in 1999 in the days after a $M_{\mathrm{L}} 4.4$ earthquake located $\sim 15 \mathrm{~km}$ west of the volcano (Moran et al., 2002). These fluctuations occurred in the context of months-long seismic unrest that culminated in a sub-Plinian eruption 5 days after the $M_{\mathrm{L}} 4.4$ earthquake (an aftershock to the 4 March 1999, $M_{\mathrm{L}} 5.2$ mainshock that is thought to have occurred in response to magma intrusion at Shishaldin [Moran et al., 2002; Nye et al., 2002]). If the fluctuations observed in 1999 were in fact triggered by the nearby local earthquake, then the absence of any obvious disruption after the DFE suggests that the Shishaldin magmatic system was in a more stable steady-state mode in 2002 and, therefore, may have been less susceptible to perturbation by large stress/strain transients from regional earthquakes than it was in 1999.

Thus, with the exception of the KVC, Alaskan volcanoes showed no significant short-term seismic response to the DFE. Even if local events did occur while seismometers were clipped, the relative lack of a short-term seismic response to the DFE by Alaskan volcanoes is especially impressive given 


\section{VNSS}

\section{$11 / 03 / 2002$}

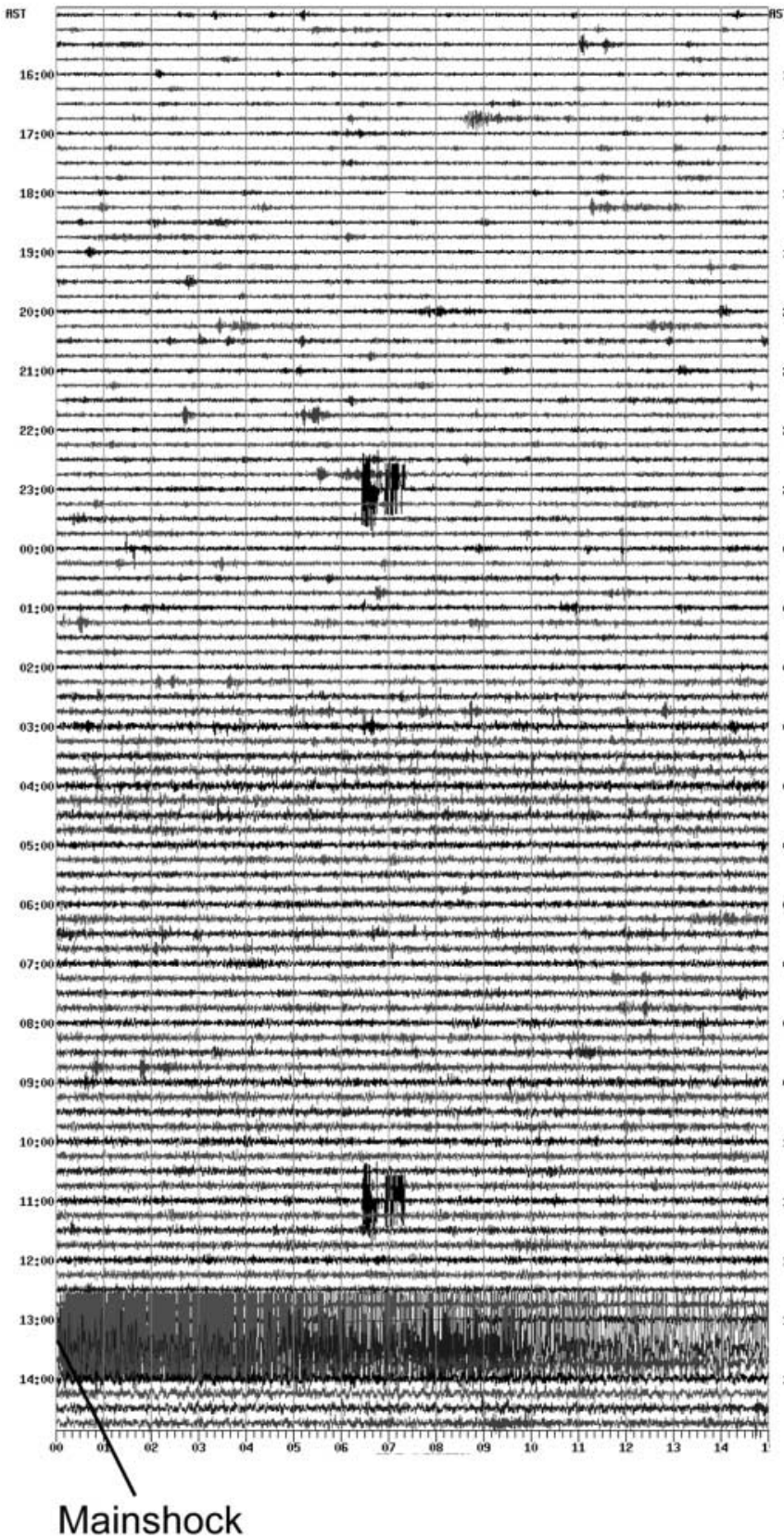

\section{$11 / 04 / 2002$}

An -

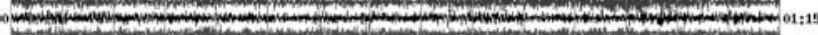
20

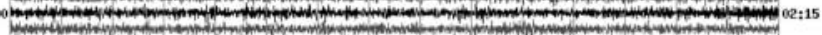

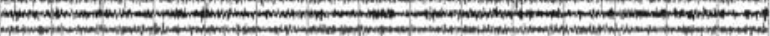

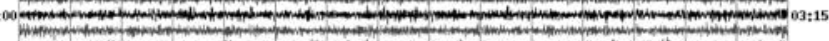
10

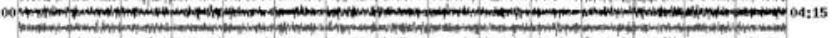
$05: 15$

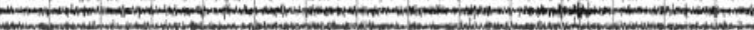

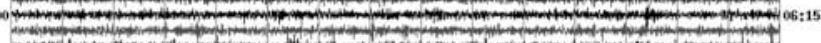

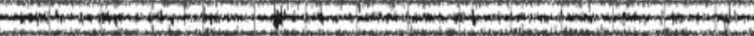

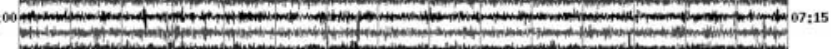

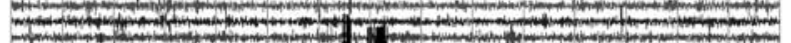

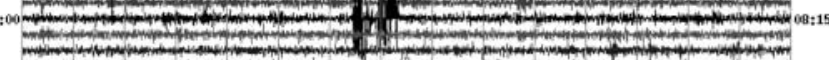
$0_{0}^{2}$ (1)

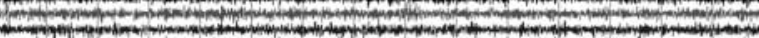

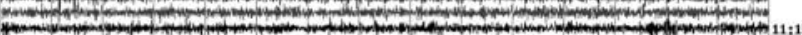
Lon -

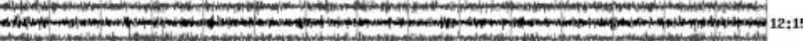

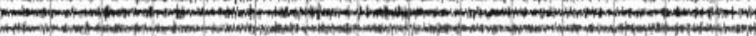

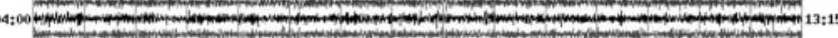

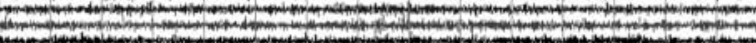
14:15 $70+10$

6:000

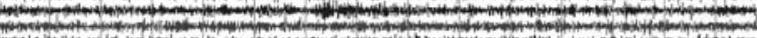

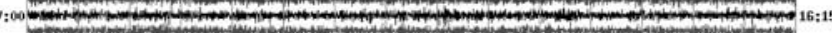

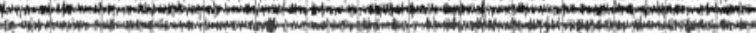
000 mon-

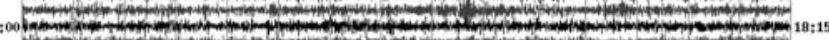

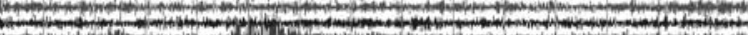

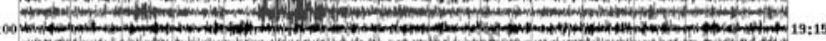

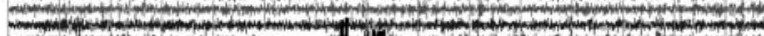

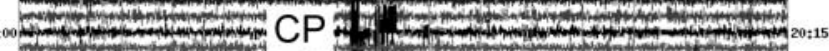

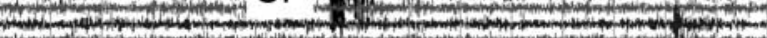

$2: 00$ -

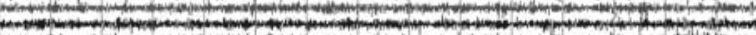

00 mbotom

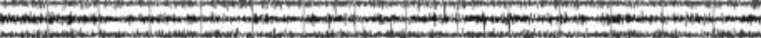

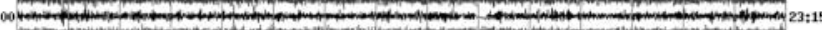

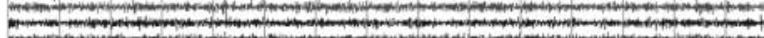

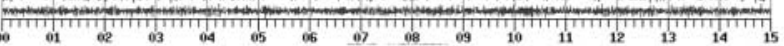

15 minutes

Figure 4. Twenty-four-hour helicorder plots from station VNSS on Veniaminof volcano for the 24-hr periods before and after the DFE. Wind noise increased throughout 3 November and largely masked smaller events on 4 November, making event counts difficult. "CP" denotes calibration pulse (two per plot). Plots were generated using "Heli_ew," a module of the EARTHWORM data-acquisition system (e.g., Bittenbinder et al., 1994). 
$11 / 03 / 2002$

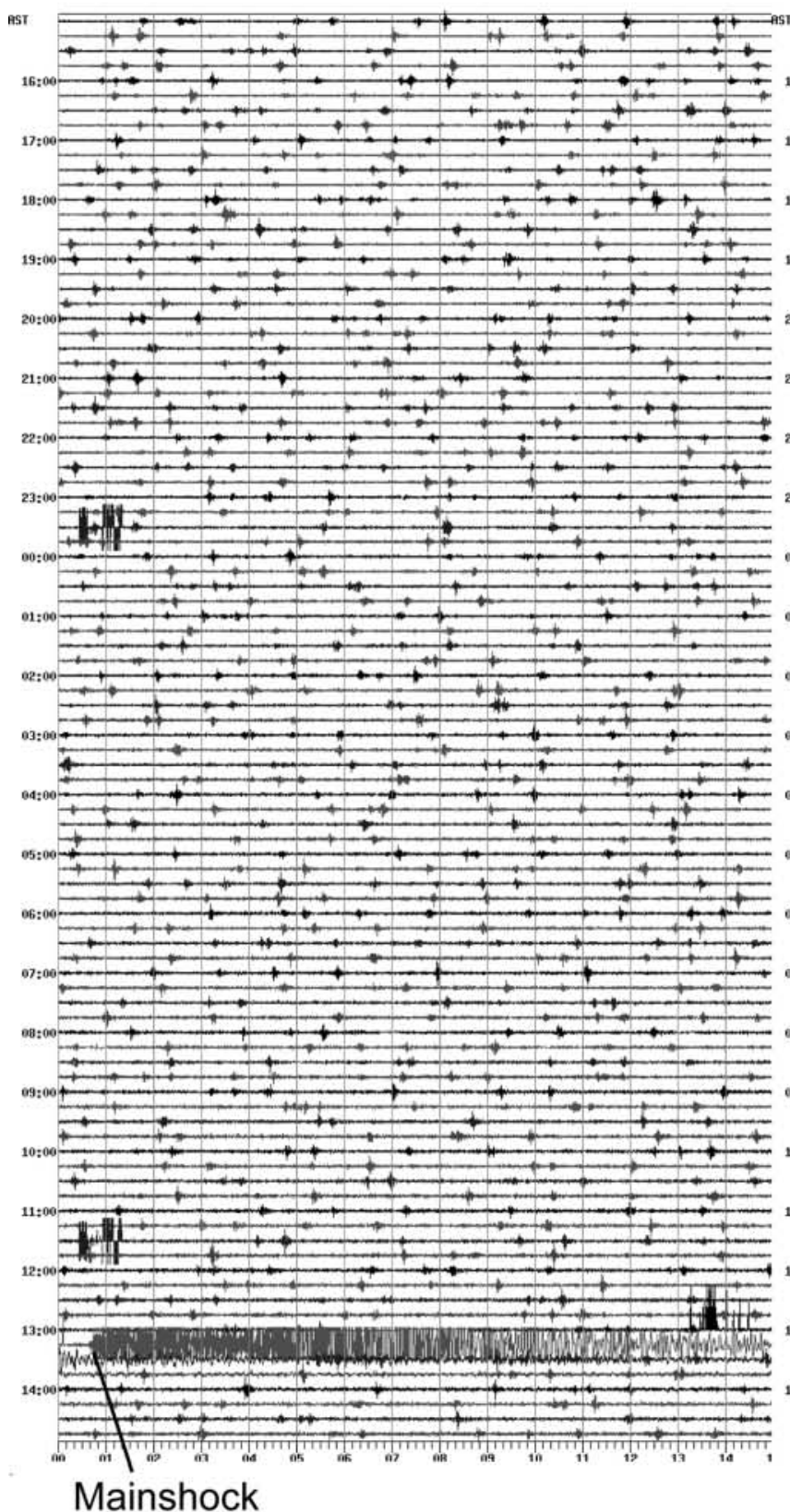

Mainshock

SSLN Hourly Counts

(b)

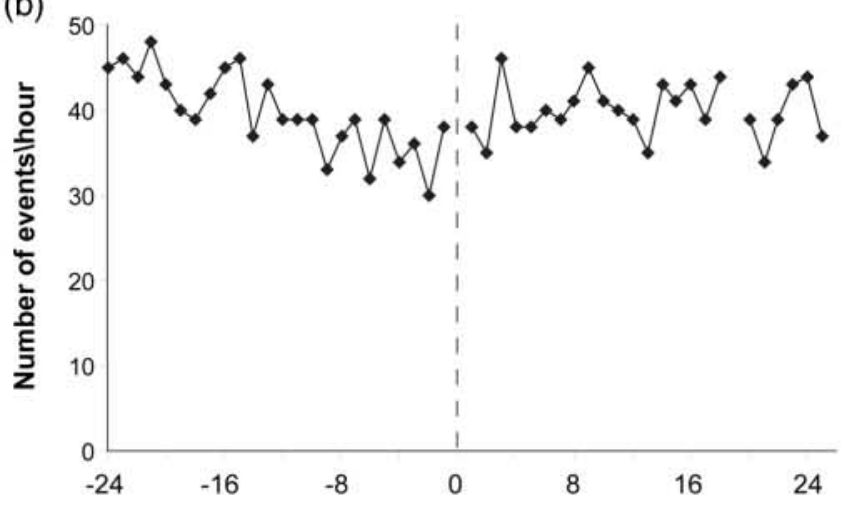

Time (hours, relative to mainshock)

\section{$11 / 04 / 2002$}

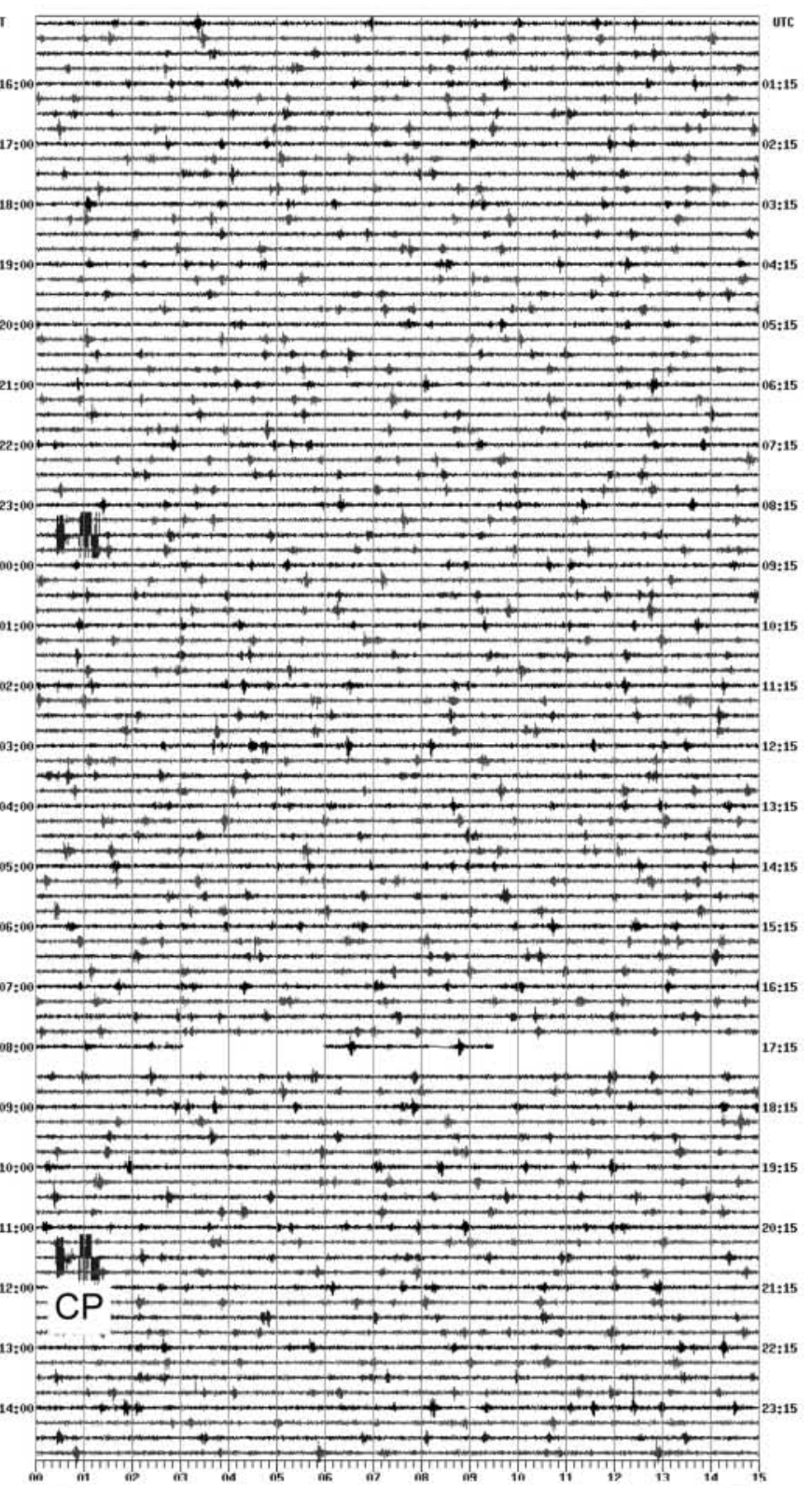

15 minutes
Figure 5. (a) Twenty-four-hour helicorder plots from station SSLN on Shishaldin volcano for the 24hr periods before and after the DFE. "CP" denotes calibration pulse (two per plot). (b) Graph of hourly event counts on SSLN for the same period shown in (a), showing no change in event rate. 
the increases in seismicity observed at Yellowstone (Husen et al., 2004), Utah (Pankow et al., 2004), Mammoth Mountain (Prejean et al., 2004), and elsewhere. The absence of any short-term seismic response suggests either that dynamic stresses were smaller at Alaskan volcanoes relative to other locations because of directivity effects, or that most Alaskan volcanoes are not susceptible to triggering by remote large earthquakes. Evidence for relatively small dynamic stresses comes from the AUL broadband recording (Fig. 3), where peak dynamic stresses (assuming 0.1 MPa $\sim 1 \mathrm{~cm} / \mathrm{sec}$ [Hill et al., 1993]) were $0.06 \mathrm{MPa}$ on the vertical and $0.1 \mathrm{MPa}$ on the horizontal components. This is a factor of 2-3 less than the values of 0.19-0.3 MPa reported by Pankow et al. (2004) for north-central Utah, indicating that directivity effects were strong (Velasco et al., 2004). However, triggering also occurred at the Coso geothermal field, where measured peak dynamic stresses were $\sim 0.01 \mathrm{MPa}$ (Prejean et al., 2004), illustrating that different volcanic systems likely have different triggering thresholds. Thus, although dynamic stresses were certainly smaller at most Alaskan volcanoes than elsewhere because of directivity effects, this does not in and of itself explain why triggering was not observed at other volcanoes, particularly those closer than the KVC to the DFE.

\section{Why Triggering Only at Katmai?}

\section{Katmai Seismicity Characteristics}

AVO installed a five-station short-period network at Katmai National Park in 1995, expanding it to 11 stations in 1996 and then to the current 18-station network in 1998 (Moran, 2003) (see Fig. 6). The seismic network monitors seven historically active volcanoes in the KVC, including Martin, Mageik, Trident, Novarupta, Griggs, Mount Katmai, and Snowy. The Katmai area has the highest background seismicity rate, in terms of located earthquakes, of any seismically monitored volcanic region in Alaska (Moran, 2003), with an average of three locatable events per day, accounting for roughly $30 \%$ of all located earthquakes in the AVO catalog between 1995 and 2002. The vast majority are volcanotectonic (VT) earthquakes (e.g., Lahr et al., 1994) with shallow depths (typically $z<5 \mathrm{~km}$ ) that occur in several spatially distinct clusters associated with volcanic centers (Fig. 6). This overall seismicity pattern is unchanged from that observed on a previous seismic network between 1987 and 1991 by Ward et al. (1991).

\section{A History of Triggered Seismicity}

Since 1996, five regional events (including the DFE) with $M_{\mathrm{W}} \geq 6.8$ have occurred within $800 \mathrm{~km}$ of the KVC (Fig. 6, Table 1). Power et al. (2001) described the first known incidence of triggered seismicity in Alaska, a series of small $\left(M_{\mathrm{L}}<1.3\right)$, shallow (depth $\left.<5.0 \mathrm{~km}\right)$, VT-type events after the $M_{\mathrm{W}}$ 7.0 Karluk Lake earthquake on 6 December 1999 (event 1 in Fig. 6 and Table 1). The Karluk

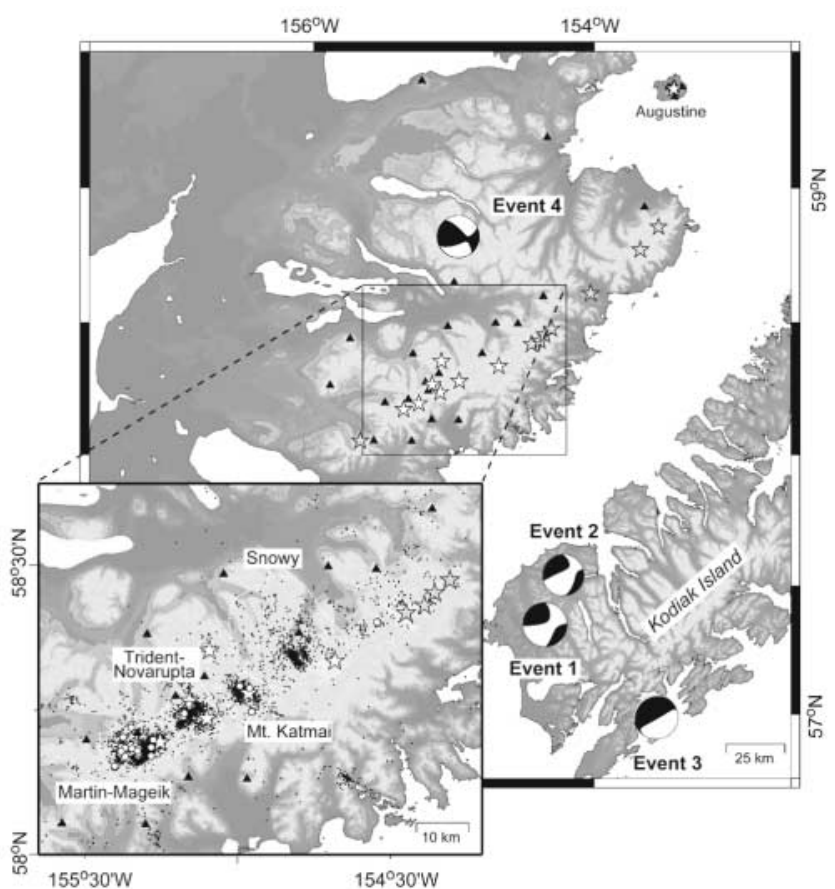

Figure 6. Map showing location and moment tensor solutions (taken from the Harvard Centroid Moment Tensor database) for the first four regional events in Table 1. Inset map shows seismicity in the Katmai Volcanic Cluster (KVC), with 1996-2002 earthquakes shown as small black dots and triggered VT events shown as white circles. The dashed lines outline the four clusters of seismicity in the KVC (e.g., Moran, 2003). For both maps, white stars represent historically active volcanoes, gray stars represent other volcanoes, and black triangles represent AVO seismic stations.

Lake earthquake was a Benioff zone event located 60-100 $\mathrm{km}$ southeast of the KVC. Triggering was characterized both by a short-term increase in the number of locatable earthquakes occurring in the first $12 \mathrm{hr}$ after the mainshock and by the presence of unlocatable VTs in the mainshock coda. The unlocatable events were first seen $\sim 3$ min after the mainshock on station $\mathrm{ACH}$, a three-component station $\sim 5$ $\mathrm{km}$ west-northwest of Mageik volcano, which suffered a significantly shorter duration of clipping $(163 \mathrm{sec})$ than other stations in the network. Power et al. (2001) showed that static stress changes were likely too small $(<0.01 \mathrm{MPa})$ to have triggered earthquakes, suggesting that dynamic stresses associated with passing waves likely caused triggering. No triggered earthquakes were observed at other nearby volcanoes, including Augustine volcano $(560 \mathrm{~km}$ from the epicenter).

Moran et al. (2001) documented the response of the $\mathrm{KVC}$ to three other large regional events (Fig. 6), including a $M_{\mathrm{W}} 6.8$ event on 11 July 2000 (event 2 ), a $M_{\mathrm{W}} 7.0$ event on 10 January 2001 (event 3), and a $M_{\mathrm{W}} 6.8$ event on 28 July 2001 (event 4). All three were Benioff zone events that were located farther from the KVC than event 1 (Table 1). 
Like event 1, small VT events could be seen in the coda of event 3 that were obviously local to the KVC (Fig. 7), and a short-term increase in the number of located VT events was noted (Fig. 8, Table 1). No VTs were observed in the codas of either event 2 or 4 (Fig. 7); however, there was a small increase in located earthquakes (five events in $3 \mathrm{hr}$ ) after event 2 (Fig. 8). All located earthquakes were small and shallow and had the same character as KVC background seismicity. A total of 41 earthquakes occurred in the KVC within $12 \mathrm{hr}$ of the four triggering regional events; 28 were located in the Martin-Mageik cluster, 8 in the Trident-Novarupta cluster, and 3 in the Mount Katmai cluster (Fig. 6), in approximate proportion to the number of located earthquakes in each cluster since 1995 (Moran, 2003). Two of the events after event 1 occurred in an area of minimal background seismicity (Power et al., 2001) and could represent "new" earthquakes (i.e., earthquakes that occurred only because of dynamic stresses associated with the passing seismic waves [Gomberg et al., 1997]). The number of VT events declined rapidly with time after each of the four regional earthquakes, with most VT events occurring in the first $3 \mathrm{hr}$ after the mainshock.

To investigate the statistical significance of short-term increases in located earthquakes after four of the five regional events, we binned the Katmai catalog between $1 \mathrm{Au}-$ gust 1996 and 31 December 2002, into 18,752 3-hr intervals. Using a definition of a swarm as any 3-hr interval with at least five earthquakes (i.e., the number of located events after event 2), we found 104 swarms in the catalog. Assuming a Poissonian process of constant rate, the probability of any one of the 104 swarms occurring within 20 min of a specific event is $\sim 0.0006$. From a short-term perspective, therefore, it is highly unlikely that the four short-term increases oc-

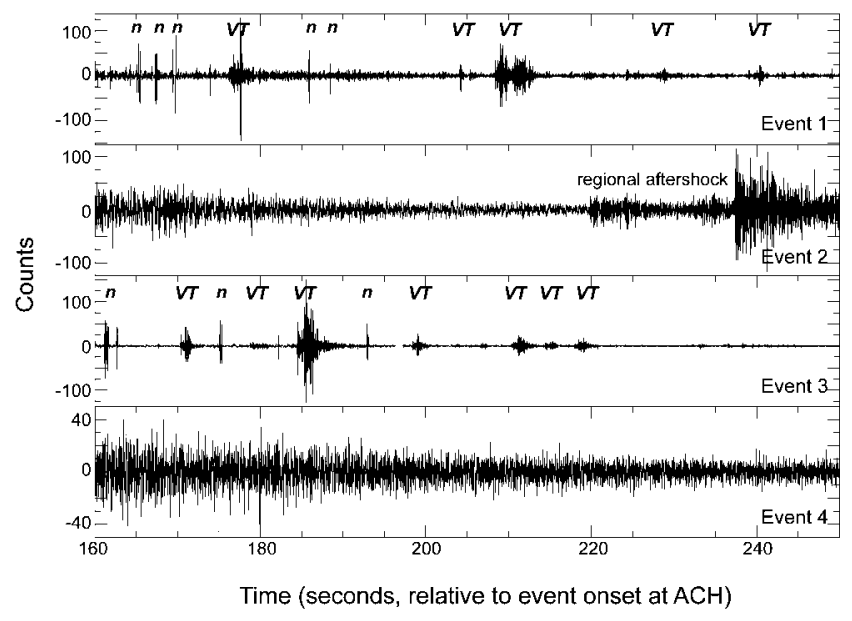

Figure 7. Seismograms from station ACH (Fig. 6) showing the coda of the first four regional events listed in Table 1 high-pass filtered with a $10-\mathrm{Hz}$ corner frequency. Time is relative to $5 \mathrm{sec}$ before event onset. Noise spikes are labeled as "n," local VT events as "VT." curred by chance, suggesting that events 1, 2, 3, and 5 (the DFE) all resulted in triggered seismicity in the KVC.

The vast majority of triggered earthquakes closely resemble "normal" KVC earthquakes in terms of size, location, and type. This suggests that most triggered earthquakes are events whose clocks were advanced by transient loads (e.g., Gomberg et al., 1997). If true, then a period of fewer-thannormal events should follow each case of triggering. Power et al. (2001) noted a 7-day period of apparent quiescence following the triggered events of event 1 . From Figure 8 it appears as if there was also quiescence following events 2 , 3 , and 5 . However, the relatively small number of triggered earthquakes after the other three events makes it difficult to

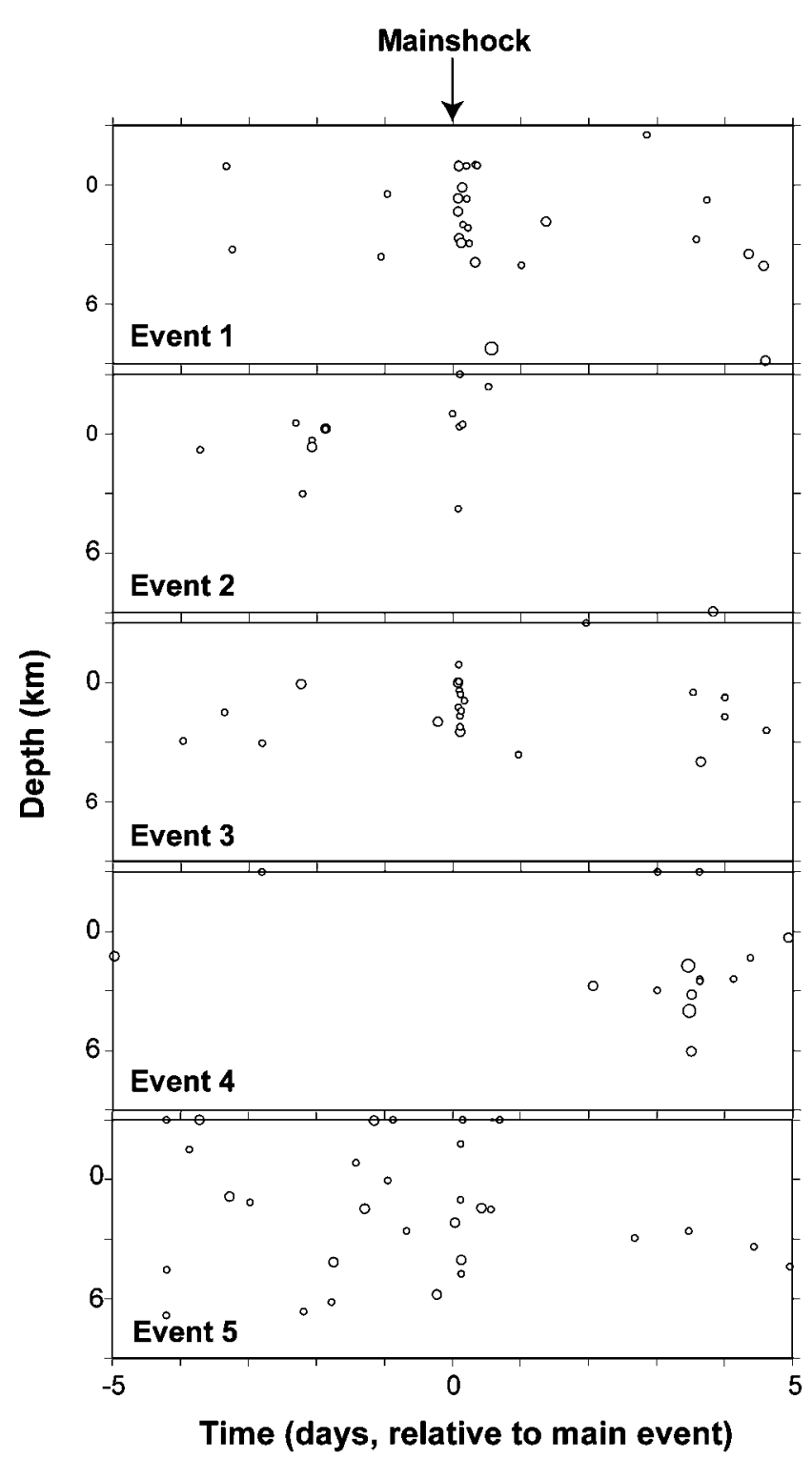

Figure 8. Time versus depth plot for all located earthquakes (hollow circles) occurring within \pm 5 days of the onset of each of the five regional events listed in Table 1. 
confirm with any certainty whether quiescence in fact occurred.

\section{Controls on Triggering}

Events 3 and 4 were roughly equidistant from the KVC and had similar radiation patterns (note that the KVC is located in roughly the middle of the dilatational quadrant in the moment tensors for events 3 and 4 in Fig. 6), yet event 4 did not trigger seismicity. This suggests that a triggering threshold may exist. Power et al. (2001) searched the AVO catalog for sudden increases in located events at Katmai after nine additional $M_{\mathrm{W}} \geq 6$ events within $1250 \mathrm{~km}$ of Katmai and found none. Given the distances over which triggered seismicity was observed after the DFE, we extended this search to include $42 M_{\mathrm{W}}>6$ events located within $2500 \mathrm{~km}$ of Katmai (as measured from Mageik volcano) occurring between 1996 and 2003 (including the 23 October 2002 $M_{\mathrm{W}} 6.7$ Nenana Mountain and 17 November $2003 M_{\mathrm{W}} 7.8$ Rat Islands earthquakes), and we similarly found no significant increases in located events except for the four events described previously.

Figure 9 shows the relationship between distance, magnitude, and triggering for these 42 events. Assuming that the triggering threshold is constant through time, one can predict, based on this plot, that all events falling above the dashed line in Figure 9 should trigger seismicity in the KVC. Stark and Davis (1996) and Gomberg and Davis (1996) found a similar distance-magnitude relationship for triggering at The Geysers. Gomberg and Davis (1996) demonstrated that triggering at The Geysers depends on a frequency-dependent strain threshold that increases with decreasing frequency. Brodsky and Prejean (2003) also found that triggering was frequency dependent at Long Valley. Comparison of this article's Figure 9 with figure 1 from Gomberg and Davis (1996) reveals that the triggering threshold at Katmai may be higher than at The Geysers. In particular, both event 4 and the $2003 M_{\mathrm{W}} 7.8$ Rat Islands earthquake, neither of which triggered seismicity at Katmai, would plot well above the triggering threshold at The Geysers. However, given the lack of any on-scale measurements at Katmai, we cannot directly determine the nature of the threshold in terms of absolute values of dynamic stresses and strains, nor can we investigate frequency dependence. If the peak dynamic stresses of $0.1 \mathrm{MPa}$ recorded at AUL on nearby Augustine volcano can be extrapolated to the Katmai area (135-175 km west-southwest of Augustine), then this may place an upper limit on the minimum dynamic stresses required for triggering at Katmai.

\section{Reasons for Triggering at Katmai}

Although we lack on-scale measurements of strain and stress transients associated with the five events, enough is known about triggering at the $\mathrm{KVC}$ and the nature of $\mathrm{KVC}$ magmatic systems from other work to permit speculation as

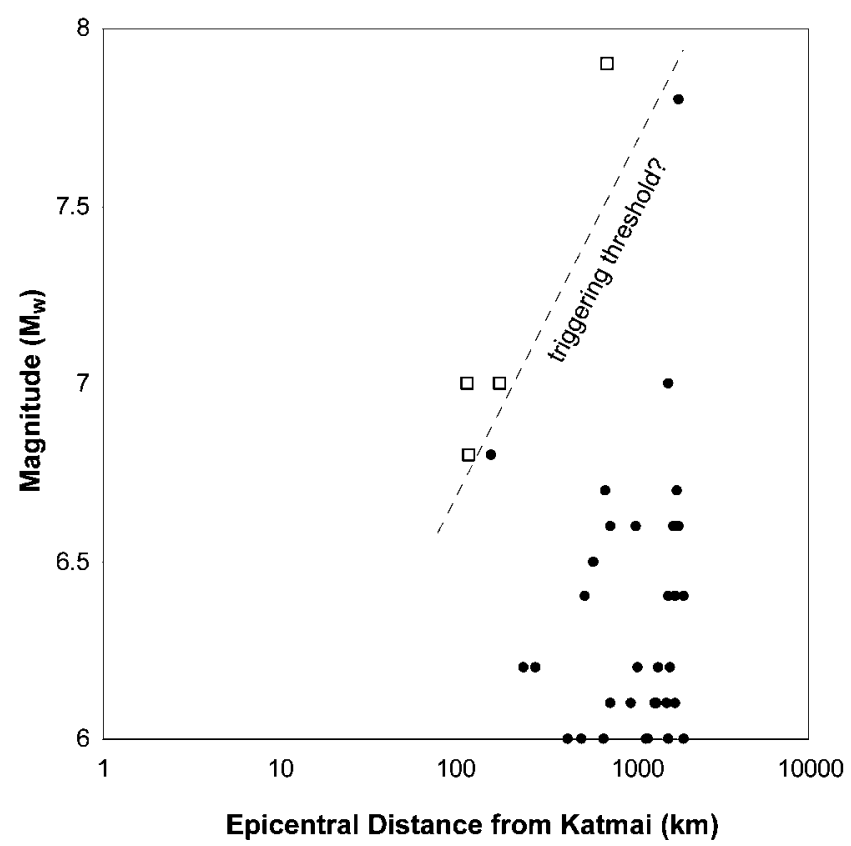

Figure 9. Plot of magnitude versus logarithm of distance (from Mageik volcano in the KVC) for all $M_{\mathrm{W}}>6$ earthquakes occurring between 1 July 1996 and 30 November 2003 within $2000 \mathrm{~km}$ of Katmai. This includes the 17 November $2003 M_{\mathrm{W}} 7.8$ event in the Rat Islands (1826 km from the KVC), which did not trigger any seismicity. Hollow squares correspond to events that triggered seismicity in the $\mathrm{KVC}$, solid circles correspond to events that did not. Dashed line represents possible triggering threshold.

to the mechanisms responsible for triggering in the KVC. The elevated background seismicity at Katmai suggests that the shallow crust contains more faults that are close to the point of failure relative to other volcanic areas in Alaska. Reasons for this may include higher pore pressures due to circulation of magmatic-hydrothermal fluids, locally elevated deviatoric stresses due to magmatic processes (expansion, contraction, elevated geothermal gradients, etc.), and/ or weaker faults due, for example, to a localized extensional environment (e.g., Hough and Kanamori, 2002) or geochemical weakening.

Anomalies in gravity, seismic velocities, and seismic attenuation at Martin-Mageik and Trident-Novarupta support the presence of magma at shallow depths near those seismicity clusters (Ward et al., 1991; Jolly, 2000; Moran, 2003). Jolly and McNutt (1999) and Moran (2003) found evidence that pore pressure increases associated with hydrothermal circulation of magmatically derived fluids likely play a key role in earthquake generation in the KVC. Jolly and McNutt (1999) and Jolly (2000) found $b$-value distributions in the KVC clusters, which can reflect the nature of geothermal gradients, the degree of crack heterogeneity, and levels of effective or applied stress (e.g., Wiemer and McNutt, 1997), to be spatially heterogeneous; we found no sim- 
ple relationship between their $b$-values and the loci of triggered seismicity.

Many mechanisms have been proposed by other investigators to explain remote triggering of seismicity, including advective overpressure (Linde et al., 1994), rectified diffusion (Brodsky et al., 1998), blockage rupturing in fractures sealed by precipitates in a confined aquifer or hydrothermal system (Brodsky et al., 2003), changes in the state of a fault or friction across a fault surface leading to clock advances (Gomberg et al., 1997, 1998; Hough and Kanamori, 2002), and changes in the state of crystallizing magma bodies (such as sinking crystal plumes and magma body relaxation) induced by passing seismic waves (Hill et al., 2002). Because most triggered earthquakes in the KVC occur relatively soon (seconds to hours) after the passage of seismic waves, mechanisms that require delays of hours to days (advective overpressure, rectified diffusion, changes in state of magma bodies) are the least likely sources of triggering at the KVC. Given that KVC seismicity appears to be related to hydrothermal circulation of magmatically derived fluids and that triggered seismicity is similar in nature and location to background seismicity, it seems reasonable to infer that fluids play a key role in the occurrence of KVC triggered seismicity as well. The blockage-rupturing model of Brodsky et al. (2003) is consistent with many aspects of KVC triggered seismicity, including relatively instantaneous occurrence of triggered earthquakes during passage of seismic waves, the small size of most triggered earthquakes, and the occurrence of triggered earthquakes mainly in regions with active hydrothermal circulation. We note that this model also requires quiescence after triggering, which may have occurred after the four events that triggered KVC seismicity (Fig. 8).

Reasons for the absence of short-term triggering at other Alaskan volcanoes, particularly those closer to the DFE, are less clear. Other Alaskan volcanic centers also have active magmatic-hydrothermal systems, although perhaps not as spatially extensive as those at Katmai if viewed as a whole. Unfortunately, little is known about the nature of any of these systems, making direct comparisons between systems at Katmai and other volcanic areas impossible. At present the best we can say is that the presence of triggering at Katmai, and lack of it elsewhere, suggests that some aspect of the KVC magmatic-hydrothermal systems is fundamentally different from those at other Alaskan volcanoes.

\section{Conclusions}

After the DFE, we scanned records from all AVO seismic stations for $\sim 1 \mathrm{hr}$ following the event onset and found evidence of short-term earthquake triggering only in the Katmai area (720-755 km southwest of the epicenter). We saw no obvious changes in seismicity at two volcanoes, Veniaminof and Shishaldin, which were seismically restless at the time of the DFE. The lack of seismic response of Alaskan volcanoes is in marked contrast to triggering observed at Yellowstone, Long Valley, and other sites in North America, many at distances $>3000 \mathrm{~km}$ from the epicenter (e.g., Eberhart-Phillips et al., 2003). The scarcity of triggering in Alaska may be due to directivity effects; peak dynamic stresses of $\sim 0.1 \mathrm{MPa}$ at Augustine volcano were two to three times lower than dynamic stresses recorded in Utah (Pankow et al., 2004; Velasco et al., 2004). However, triggering was observed at other North American sites where peak dynamic stresses were less than 0.1 MPa (e.g., Prejean et al., 2004), indicating that triggering thresholds vary from system to system. The Katmai area is particularly susceptible to triggering, because three other large $\left(M_{\mathrm{W}}>6.7\right)$ regional events have triggered earthquakes there since 1999. Triggered earthquakes at Katmai appear to be clock-advanced "background" earthquakes associated with seismically active magmatic-hydrothermal systems (e.g., Jolly and McNutt, 1999; Moran, 2003). The absence of triggering at other Alaskan volcanoes indicates that Katmai has a lower triggering threshold, which suggests that the magmatic-hydrothermal systems beneath the Katmai volcanoes are fundamentally different than those at other Alaskan volcanoes.

\section{Acknowledgments}

We thank John Paskievitch, Tim Plucinski, Guy Tytgat, and others responsible for the installation and maintenance of the AVO seismic networks at Katmai National Park and other Alaskan volcanoes. We also thank the National Park Service and the Fish and Wildlife Service for allowing access to sites on volcanoes within their jurisdiction. We are grateful for thoughtful reviews from Dan Dzurisin, Elliot Endo, Sue Hough, Stefan Husen, Stephanie Prejean, and Charlotte Rowe, which clarified our thinking on several key points and significantly improved the article. Several figures were created with Generic Mapping Tools (GMT) (Wessel and Smith, 1998) and Seismic Analysis Code (SAC) (e.g., Goldstein and Minner, 1996) software packages.

\section{References}

Bittenbinder, A. N., B. M. Bogaert, C. E. Johnson, and S. D. Malone (1994). Earthworm; a modular distributed processing approach to seismic network processing (abstract), Seism. Res. Lett. 65, 51.

Bodin, P., J. Gomberg, K. Larson, and H. Dragert (2003). The common phenomenon of transient triggered seismicity (abstract), EOS 84, (Fall Meeting Suppl.), S11H-01.

Brodsky, E. E., and S. G. Prejean (2003). Frequency-dependent dynamic triggering (abstract), EOS 84, (Fall Meeting Suppl.), S31G-05.

Brodsky, E. E., V. Karakostas, and H. Kanamori (2000). A new observation of dynamically triggered regional seismicity; Earthquakes in Greece following the August, 1999 Izmit, Turkey earthquake, Geophys. Res. Lett. 27, 2741-2744.

Brodsky, E. E., E. Roeloffs, D. Woodcock, I. Gall, and M. Manga (2003). A mechanism for sustained groundwater pressure changes induced by distant earthquakes, J. Geophys. Res. 108, no. B8, 2390, doi 10.1029/ 2002JB002321

Brodsky, E. E., B. Sturtevant, and H. Kanamori (1998). Volcanoes, earthquakes and rectified diffusion, J. Geophys. Res. 103, 23,827-23,838.

Caplan-Auerbach, J., T. Petersen, and S. R. McNutt (2002). Unusual hybrid earthquakes at Shishaldin volcano, Alaska, EOS Trans. AGU 83, no. 47 (fall meeting suppl.), abstract V21A-1172.

Dixon, J. P., S. D. Stihler, J. A. Power, G. Tytgat, S. C. Moran, J. Sánchez, S. Estes, S. R. McNutt, and J. Paskievitch (2003). Catalog of earthquake hypocenters at Alaskan Volcanoes: January 1 through December 31, 2002, U.S. Geol. Surv. Open-File Rept. 03-267, 58 pp. 
Eberhart-Phillips, D., P. J. Haeussler, J. T. Freymueller, A. D. Frankel, C. M. Rubin, P. Craw, N. A. Ratchkovski, G. Anderson, A. J. Crone, T. E. Dawson, H. Fletcher, R. Hansen, E. L. Harp, R. A. Harris, D. P. Hill, S. Hreinsdóttir, R. W. Jibson, L. M. Jones, D. K. Keefer, C. F. Larsen, S. C. Moran, S. F. Personius, G. Plafker, B. Sherrod, K. Sieh, and W. K. Wallace, (2003). The 2002 Denali fault earthquake, Alaska: a large magnitude, slip-partitioned event, Science 300, 1113-1118.

Goldstein, P., and L. Minner (1996). SAC2000; seismic signal processing and analysis tools for the 21st century (abstract), Seism. Res. Lett. 67,39 .

Gomberg, J., and S. Davis (1996). Stress/strain changes and triggered seismicity at The Geysers, California, J. Geophys. Res. 101, 733-749.

Gomberg, J., N. M. Beeler, M. L. Blanpied, and P. Bodin (1998). Earthquake triggering by transient and static deformations, J. Geophys. Res. 103, 24,441-24,426.

Gomberg, J, M. L. Blanpied, and N. M. Beeler (1997). Transient triggering of near and distant earthquakes, Bull. Seism. Soc. Am. 87, 294-309.

Gomberg, J., P. A. Reasenberg, P. Bodin, and R. A. Harris (2001). Earthquake triggering by seismic waves following the Landers and Hector Mine earthquakes, Nature 311, 462-466.

Hill, D. P., M. J. S. Johnston, J. O. Langbein, and R. Bilham (1995). Response of Long Valley caldera to the $M_{\mathrm{w}}=7.3$ Landers, California, earthquake, J. Geophys. Res. 100, 12,985-13,005.

Hill, D. P., F. Pollitz, and C. Newhall (2002). Earthquake-volcano interactions, Phys. Today 55, 41-47.

Hill, D. P., P. A. Reasenberg, A. Michael, W. J. Arabaz, G. Beroza, D. Brumbaugh, J. N. Brune, R. Castro, S. Davis, D. dePolo, W. L. Ellsworth, J. Gomberg, S. Harmsen, L. House, S. M. Jackson, M. J. S. Johnston, L. Jones, R. Keller, S. Malone, L. Munguia, S. Nava, J. C. Pechmann, A. Sanford, R. W. Simpson, R. B. Smith, M. Start, M. Stickney, A. Vidal, S Walter, V. Wong, and J. Zollweg (1993). Seismicity remotely triggered by the magnitude 7.3 Landers, California, earthquake, Science 260, 1617-1623.

Hough, S. E. (2001). Triggered earthquakes and the 1811-1812 New Madrid, central United States, earthquake sequence, Bull. Seism. Soc. Am. 91, 1574-1581.

Hough, S. E., and H. Kanamori (2002). Source properties of earthquakes near the Salton Sea triggered by the 16 October 1999 M 7.1 Hector Mine, California, earthquake, Bull. Seism. Soc. Am. 92, 1281-1289.

Husen, S., S. Wiemer, and R. B. Smith. (2004). Remotely triggered seismicity in the Yellowstone National Park Region by the $2002 M_{\mathrm{w}}=$ 7.9 Denali fault earthquake, Alaska, Bull. Seism. Soc. Am. 94, no. 6B, S317-S331.

Jolly, A. D. (2000). Subsurface structure of the volcanoes in Katmai National Park, Alaska, Ph.D. Dissertation, University of Alaska, Fairbanks.

Jolly, A. D., and S. R. McNutt (1999). Seismicity at the volcanoes of Katmai National Park, Alaska: July 1995-December 1997, J. Volcanol. Geotherm. Res. 93, 173-190.

Lahr, J. C., B. A. Chouet, C. D. Stephens, J. A. Power, and R. A. Page (1994). Earthquake location and error analysis procedures for a volcanic sequence: application to the 1989-1990 eruptions at Redoubt volcano, Alaska, J. Volcanol. Geotherm. Res. 62, 137-153.

Linde, A. T., I. S. Sacks, M. J. S. Johnston, D. P. Hill, and R. G. Bilham (1994). Increased pressure from rising bubbles as a mechanism for remotely triggered seismicity, Nature $\mathbf{3 7 1}, 408-410$.

Moran, S. C. (2003). Multiple seismogenic processes for high-frequency earthquakes at Katmai National Park, Alaska: evidence from stress tensor inversions of fault-plane solutions, Bull. Seism. Soc. Am. 93, 94-108.

Moran, S. C., J. A. Power, and S. D. Stihler (2001). Volcanic earthquake triggering by dynamic stresses associated with nearby tectonic earth- quakes: constraints from the Katmai Group volcanoes, Alaska (abstract), EOS 82, (Fall Meeting Suppl.), F837.

Moran, S. C., S. D. Stihler, and J. A. Power (2002). A tectonic earthquake sequence preceding the April-May 1999 eruption of Shishaldin Volcano, Alaska, Bull. Volcanol. 64, 520-524.

Nye, C. J., T. E. C. Keith, J. C. Eichelberger, T. P. Miller, S. R. McNutt, S. Moran, D. J. Schneider, J. Dehn, and J. R. Schaefer (2002). The 1999 eruption of Shishaldin volcano, Alaska: monitoring a distant eruption, Bull. Volcanol. 64, 507-519.

Pankow, K. L., W. J. Arabasz, J. C. Pechmann, and S. J. Nova (2004). Triggered seismicity in Utah from the 3 November 2002 Denali fault earthquake, Bull. Seism. Soc. Am. 94, no. 6B, S332-S347.

Power, J. A., S. C. Moran, S. R. McNutt, S. D. Stihler, and J. J. Sánchez (2001). Seismic response of the Katmai volcanoes to the 6 December 1999 magnitude 7.0 Karluk Lake earthquake, Alaska, Bull. Seism. Soc. Am. 91, 57-63.

Prejean, S., D. P. Hill, E. E. Brodsky, S. Hough, M. A. Johnston, S. D. Malone, D. Oppenheimer, A. M. Pitt, and K. Richards-Dinger (2004). Remotely triggered seismicity on the United States west coast following the $2002 M_{\mathrm{w}} 7.9$ Denali fault earthquake, Bull. Seism. Soc. Am. 94, no. 6B, S348-S359.

Sanchez, J. J., and S. R. McNutt (2004). Intermediate-term declines in seismicity at Mt. Wrangell and Mt. Veniaminof volcanoes, Alaska, following the $M_{\mathrm{w}}$ 7.9 Denali fault earthquake, Bull. Seism. Soc. Am. 94, no. 6B, S370-S383.

Stark, M. A., and S. D. Davis (1996). Remotely triggered microearthquakes at The Geysers geothermal field, California, Geophys. Res. Lett. 23, 945-948.

Velasco, A., C. Ammon, J. Farrel, and K. L. Pankow (2004). Rupture directivity and its effects of the 3 November 2002 Denali fault earthquake determined from surface waves, Bull. Seism. Soc. Am. 94, no. 6B, S293-S299.

Ward, P. L., A. M. Pitt, and E. Endo (1991). Seismic evidence for magma in the vicinity of Mt. Katmai, Alaska, Geophys. Res. Lett. 18, 1537 1540.

Wessel, P., and W. H. F. Smith (1998). New, improved version of the generic mapping Toolsreleased, EOS 79, 579.

Wiemer, S., and S. R. McNutt (1997). Variations in the frequency-magnitude distribution with depth in two volcanic areas: Mount St. Helens, Washington, and Mt. Spurr, Alaska, Geophys. Res. Lett. 24, 189-192.

U.S. Geological Survey-Cascades Volcano Observatory

1300 SE Cardinal Ct., Bldg. 10

Vancouver, Washington 98683

smoran@usgs.gov

(S.C.M.)

U.S. Geological Survey-Alaska Volcano Observatory

4200 University Dr.

Anchorage, Alaska 99508

jpower@usgs.gov

jca@usgs.gov

(J.A.P., J.C.-A.)

Alaska Volcano Observatory

Geophysical Institute, University of Alaska Fairbanks

903 Koyukuk Dr.

Fairbanks, Alaska, 99775-7320

stihler@giseis.alaska.edu

jjsanchez@giseis.alaska.edu

(S.D.S., J.A.S.)

Manuscript received 13 January 2004. 